$$
\text { KALP }-97-150
$$

\title{
Overview of Environmental Surveillance and Compliance at Los Alamos during 1996
}

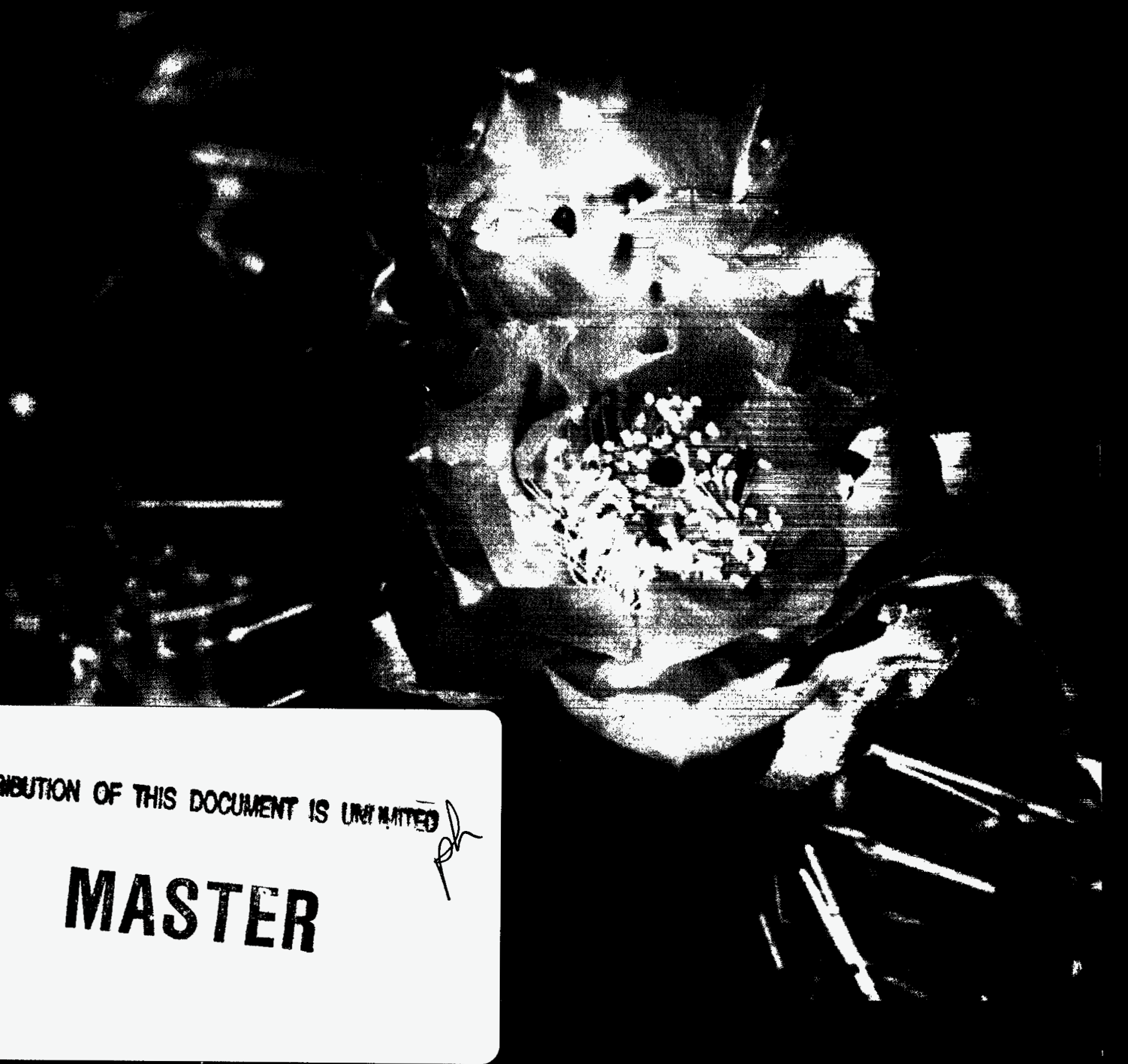


LALP-97-150

September 1997

The information presented in this overview booklet is explained in greater detail in Environmental Surveillance and Compliance at Los Alamos during 1996. If you would like a copy, please contact the Laboratory's Environmental Reports Team at 505-665-0231. 


\section{DISCLAIMER}

This report was prepared as an account of work sponsored by an agency of the United States Government. Neither the United States Government nor any agency thereof, nor any of their employees, makes any warranty, express or implied, or assumes any legal liability or responsibility for the accuracy, completeness, or usefulness of any information, apparatus, product, or process disclosed, or represents that its use would not infringe privately owned rights. Reference herein to any specific commercial product, process, or service by trade name, trademark, manufacturer, or otherwise does not necessarily constitute or imply its endorsement, recommendation, or favoring by the United States Government or any agency thereof. The views and opinions of authors expressed herein do not necessarily state or reflect those of the United States Government or any agency thereof. 


\section{DISCLAIMER}

Portions of this document may be illegible electronic image products. Images are produced from the best available original document. 


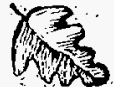

Contents

Introduction to the Los Alamos National Laboratory

2

Radiation 4

1996 Dose and Risk Estimates 5

Environmental Programs at Los Alamos National Laboratory 6

Environmental Monitoring 8

Environmental Compliance 12

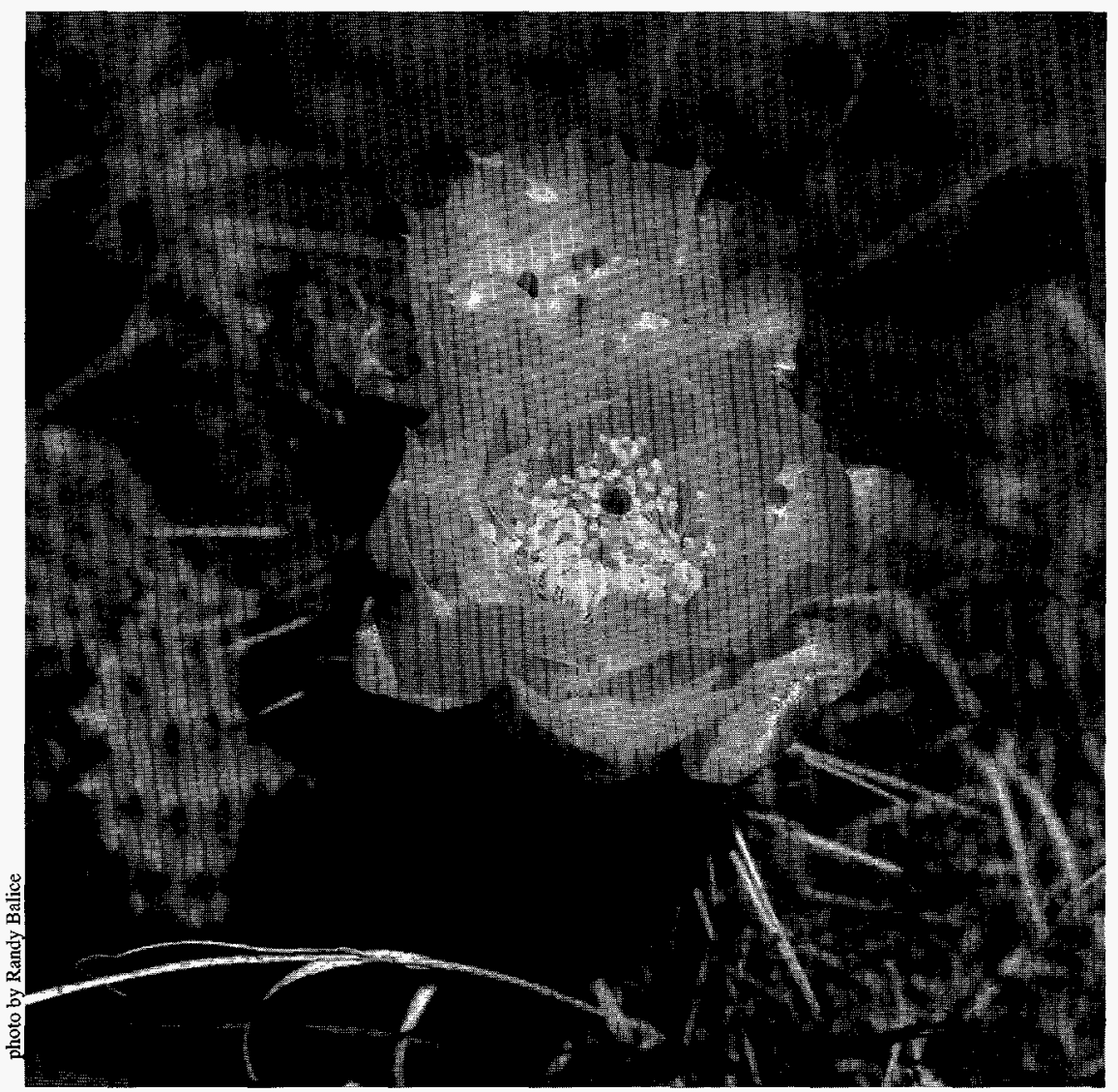




\section{Introduction to the Los Alamos National Laboratory}

Linking the Rio Grande Valley and the Jemez Mountains, New Mexico's Pajarito Plateau is home to a worldclass scientific institution. Los Alamos National Laboratory (or the Laboratory), managed by the Regents of the University of California, is a government-owned, Department of Energysupervised complex investigating all areas of modern science for the purposes of national defense, health, conservation, and ecology.

The Laboratory was founded in 1943 as part of the Manhattan Project, whose members assembled to create the first nuclear weapon. Occupying the campus of the Los Alamos Ranch School, American and British scientists gathered on the isolated mesa tops to harness recently discovered nuclear power with the hope of ending World War II. In July 1945, the initial objective of the Laboratory, a nuclear device, was achieved at Los Alamos and tested in White Sands, New Mexico. Today, the Laboratory continues its role in defense, particularly in nuclear weapons, including developing methods for safely handling weapons and managing waste.

The 43 square miles of the Laboratory are divided into 47 technical areas that are used for building sites, experimental areas, waste disposal locations, roads and utilities, and safety and security buffers. An experimental area is located west of the Laboratory in Sandoval County at Fenton Hill. The Laboratory shares the county, with twa residential communities: Los Alamos townsite and White Rock. Most of the land surrounding the Laboratory is undeveloped, owned by the Pueblo of San Ildefonso, the Bureau of Land Management, the Santa Fe National Forest, the General Services Administration, and Bandelier National
Monument, or is rural, supported by ranching and light farming. Santa $\mathrm{Fe}$, the state capital, is 25 miles southeast of Los Alamos; Española is located 20 miles to the east; and Albuquerque, New Mexico's largest city, is 60 miles to the south-southwest. In 1996, more than 246,000 people lived within a 50 mile radius of the Laboratory. The Laboratory and its contractors employed over 12,500 people; the Laboratory is the largest employer in Los Alamos County and northern New Mexico. Other local economic activity is fostered by technology transfer and tourism.

Diversity is inherent in the geography and ecology of Los Alamos. The terrain of the Pajarito Plateau, where Los Alamos is situated, alternates between mesas and deep canyons. The natural borders of Los Alamos-the Rio Grande and the Jemez Mountains-are significantly lower and higher in elevation than the mesas, which range from 6,200 feet to 7,800 feet. Six vegetation types: piñonjuniper, mixed conifer, ponderosa pine, juniper-grassland, spruce-fir, and subalpine grassland are well represented in the Los Alamos environs. Hundreds of species of wildlife, ranging from aquatic invertebrates to large mammals, reside on or near to Laboratory property. 
For the past twenty years, the Laboratory has published an annual environmental surveillance report. This pamphlet offers an overview that briefly explains important concepts, such as radiation, and provides a summary of the monitoring results and regulatory compliance status that are

explained at length in Environmental Surveillance and Compliance at Los Alamos during 1996. This information is organized in five sections: Radiation, 1996 Dose and Risk Estimates, Environmental Programs at Los Alamos National Laboratory, Environmental Monitoring, and Environmental Compliance. Please call the Laboratory's Environmental Reports Team at 505-6650231 if you have any questions about this booklet.

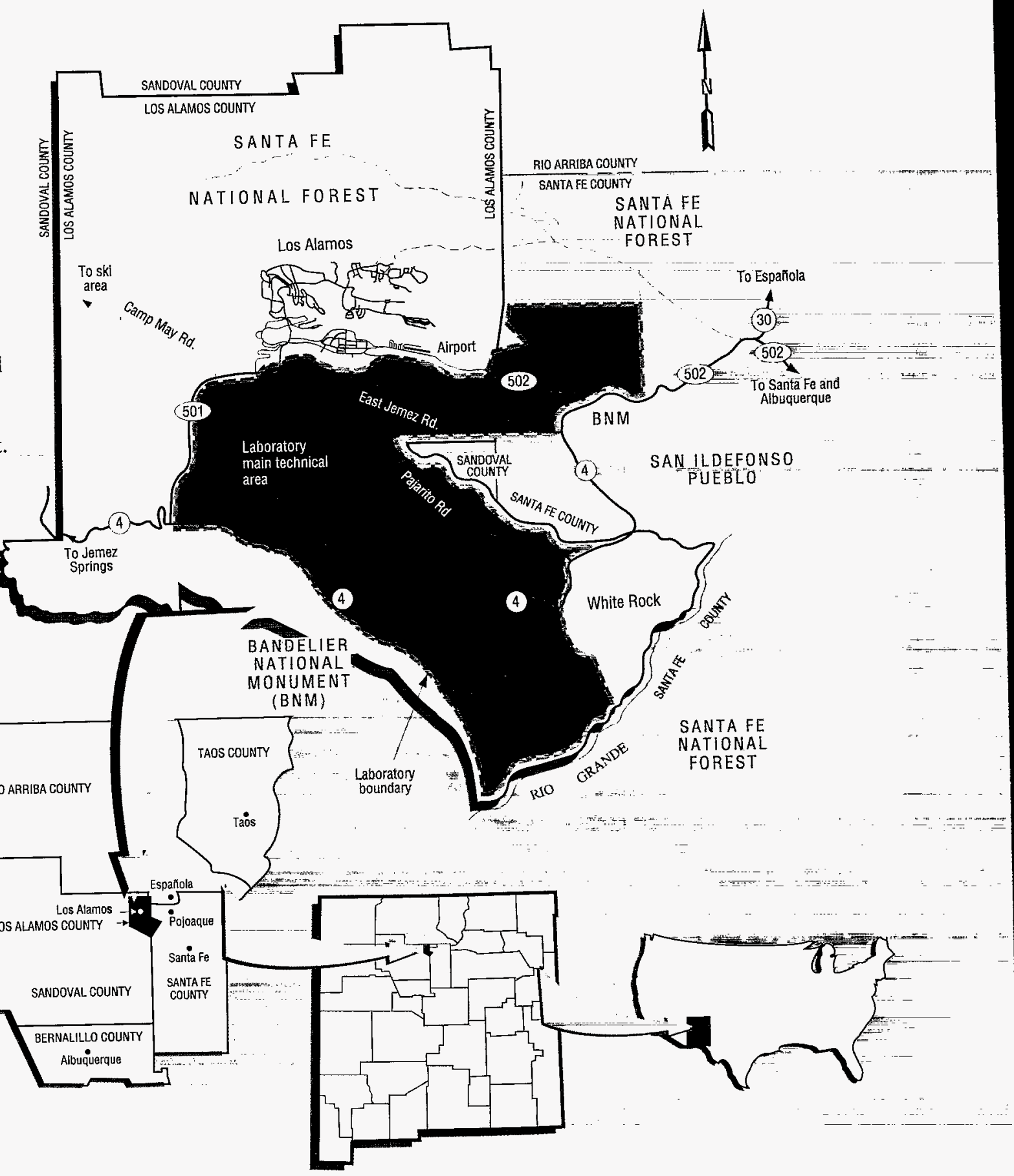


Much attention is focused on the Laboratory's use of materials containing radiation. Many of the Laboratory's activities include handling radioactive materials or operating radiation-producing equipment.

\section{background radiation}

Although some radiation is manufactured by human activities, most of it can be attributed to natural sources. Naturally occurring radiation, also called background radiation, is received by the Earth and its inhabitants every day. Although our understanding of radiation is relatively new and constantly being enhanced, radiation has always been a part of life on Earth. Radon in the air, uranium in rocks and soil, potassium fundamental to our bodies, and ultraviolet rays from the sun all contribute to the yearly natural exposure to radiation. Exposure to natural radiation depends partially on where one lives and what house-building materials are used.

Radiation from cosmic rays, terrestrial radiation, and radon contribute the most to an individual's estimated dose. There is more naturally occurring radiation in Los Alamos and White Rock residential areas as compared to the national average because of the high altitude and naturally occurring uranium.

\section{human-produced radiation}

Radiation is also produced by medical procedures and industry. Medical $\mathrm{x}$-rays are a source of radiation, as are consumer products such as tobacco products, porcelain dentures, televisions, smoke detectors, and microwave ovens.

Many of the activities and operations at the Laboratory involve or produce liquids, solids, and gases that contain radioactive and/or nonradioactive

hazardous materials. Such activities include conducting research and development programs in basic and applied chemistry and physics, testing and manufacturing explosives, cleaning chemically contaminated equipment, and working with radioactive materials.

Laboratory policy requires that operations be performed in a manner that protects the environment and addresses compliance with applicable federal and state environmental protection regulations. This policy is in accordance with Department of Energy requirements to protect the public, environment, and worker health and to comply with applicable environmental laws, regulations, and orders.

\section{pathways}

Both background and human-produced radiation have the potential to reach the public. A pathway outlines the route a radioactive contaminant may follow to reach the human population. Radioactive releases may enter the local environment by air or water and pass through soil, plants, livestock, or wildlife, ultimately reaching humans through inhalation, ingestion, or external exposure, such as absorption through skin or wounds. 


\section{dose}

The effects of radiation are related to dose, the amount of radiation received. To protect worker and public health and safety, the Department of Energy maintains dose limits based on guidance from the Environmental Protection Agency, the National Council on Radiation Protection and Measurements, and the International Commission on Radiological Protection. Radiation doses are measured in millirems and typically are assessed for the exposure of a full year.

The maximum doses permitted at Department of Energy sites are in addition to radiation from background, medical, or consumer sources. The Department of Energy's public dose limit is 100 millirem per year from all pathways: inhalation, ingestion, and external exposure. Estimates for radionuclide inhalation are adjusted for living indoors (shielding). Estimates for radionuclide ingestion are adjusted for the annual food consumption rate.

By combining the calculated maximum off-site dose with the maximum on-site dose estimate, the maximum dose a member of the public could have received from Laboratory operations during 1996 was estimated at 13.3 millirem, or $13.3 \%$ of the Department of Energy's public dose limit.

The Environmental Protection Agency limits the effective dose equivalent (an estimate of the total risk of potential effects from radiation exposure) to any member of the public from radioactive airborne releases from the Laboratory to 10 millirem per year. The 1996 effective dose equivalent is calculated to be 1.93 millirem, or $19.3 \%$ of the Environmental Protection Agency's standard.

\section{risk}

In March 1996, the Health Physics Society noted that health effects (primarily cancer) from radiation exposure are observed in humans only at doses in excess of 10 rem delivered at high dose rates.

The risk of cancer mortality for every United States resident is one chance in five. The added risk to any individual of cancer mortality caused by Laboratory operations is negligible.

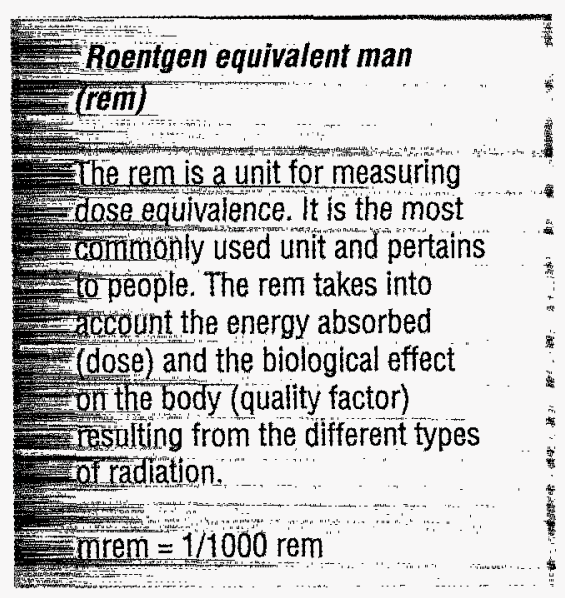

\section{National Average Annual Dose}

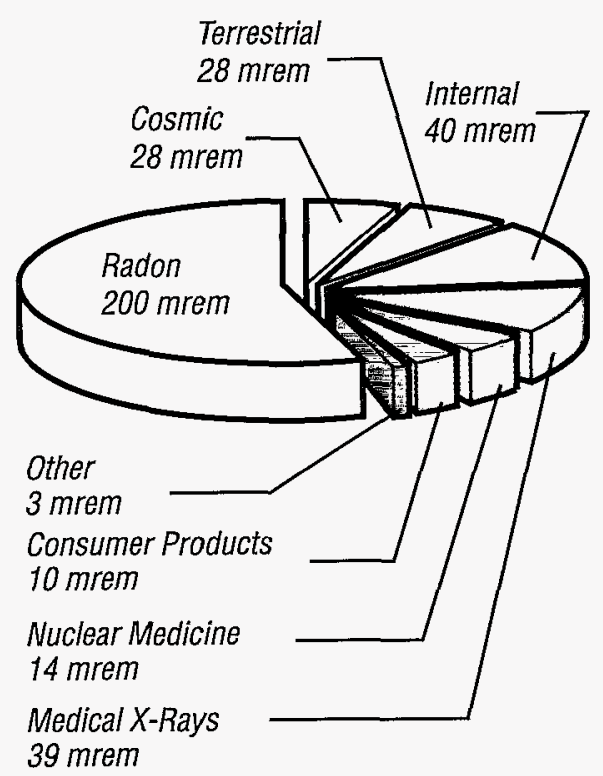

Naturally Occurring Radiation 296 mrem

Man-made Sources $66 \mathrm{mrem}$
Total contributions to 1996 dose for the Laboratory's maximum exposed individual.

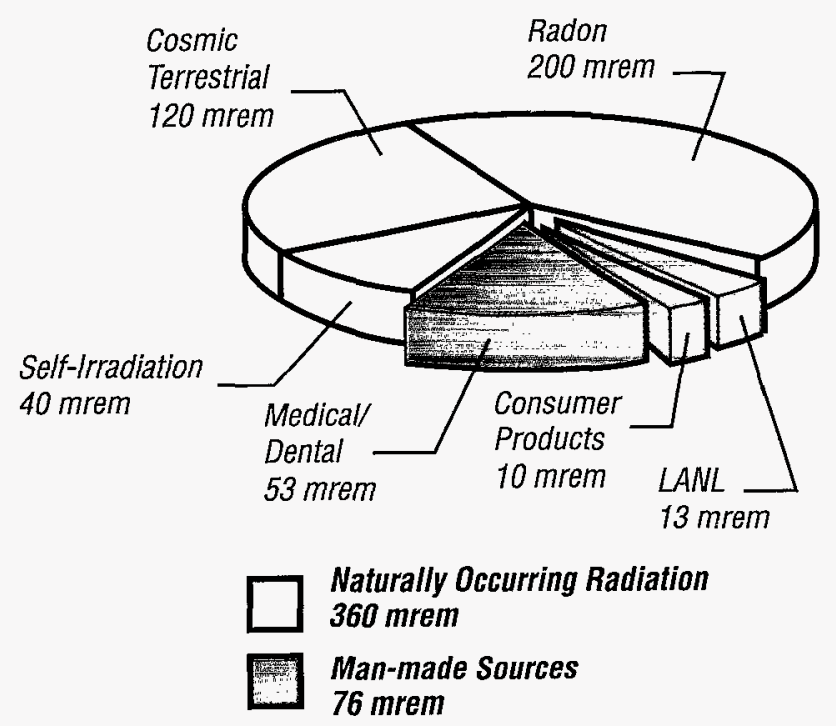




\section{Environmental Programs at Los Alamos National Laboratory}

\section{environmental protection}

Personnel in the Laboratory's Environment, Safety, and Health Division prepare permits, interpret regulations, perform and document environmental monitoring and compliance activities, and provide technical advice in the areas of air, water, sediments, soil, food, biota, and hazardous materials. Data are also gathered on measurements of natural radiation and Laboratory radiation sources. Weather conditions are monitored to assess the movement of airborne contaminants to the environment. The Environment, Safety, and Health Division also conducts cultural and biological investigations across the site.

\section{environmental restoration}

The Laboratory's Environmental Restoration Project was established in 1989 to identify the extent of possible contamination at the Laboratory and the appropriate means for restoring contaminated areas to comply with applicable laws and regulations. The Hazardous and Solid Waste Amendments to the Resource Conservation and Recovery Act govern these activities.

More than 2,500 potential release sites have been identified at the Laboratory. Potential release sites are areas that may have been contaminated over the past 50 years and range from the size of a table top to areas of several acres. These sites include past disposal sites as well as areas where spills of hazardous materials have been reported. The Environmental Restoration Project is also responsible for decontaminating and decommissioning sites and facilities that are considered surplus, such as old buildings that are no longer in use.

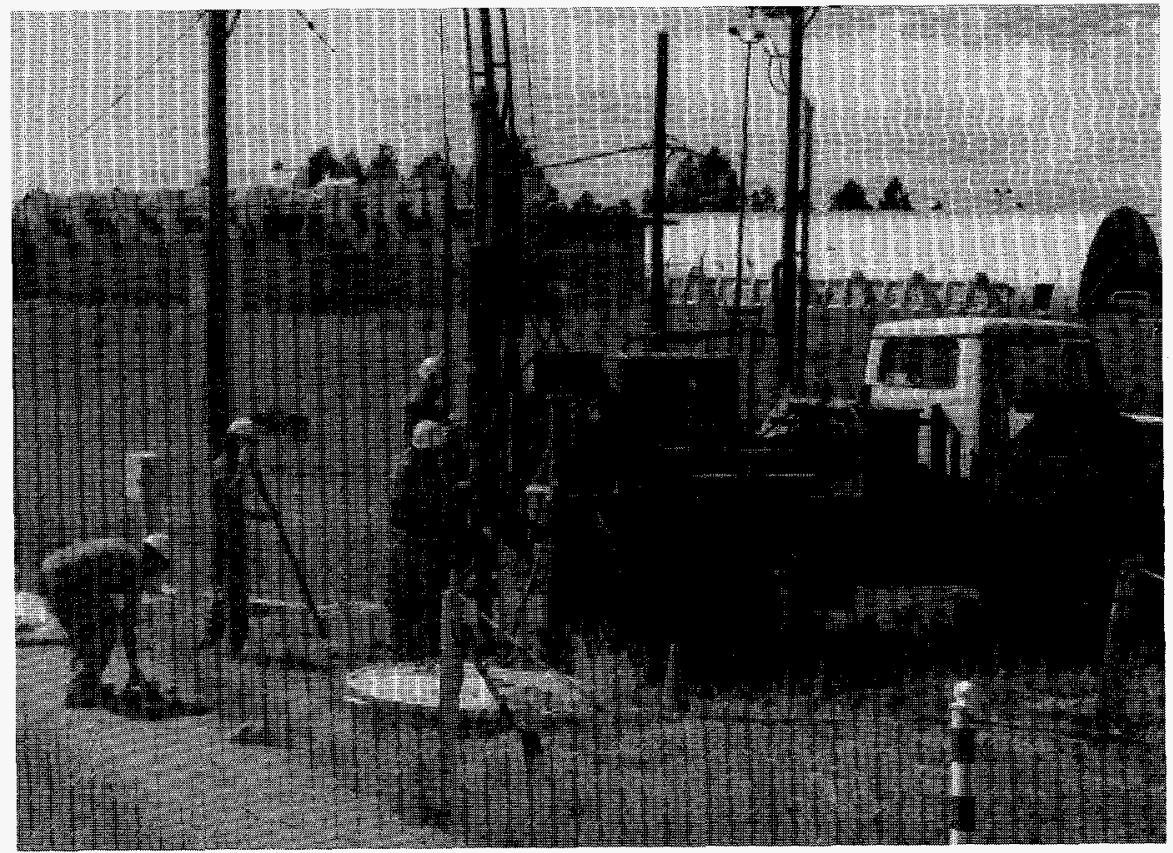

\section{waste management}

A Waste Management program is in place at the Laboratory to monitor, treat, dispose, and/or safely store radioactive waste, hazardous chemical waste, nonhazardous waste, and municipal-type sanitary waste. No high-level radioactive wastes are generated at the Laboratory. Approximately $11 \%$ of the total volume of the Los Alamos County landfill was generated by Laboratory operations during 1996. Pollution prevention and waste minimization activities are part of the Waste Management program. Accomplishments in 1996 include recycling more than 9,000 tons of materials that would have been sent to the local landfill_-office furniture, paper, and phone books.

\section{quality assurance}

The Laboratory adheres to a threefold management process to ensure quality. First, the Laboratory seeks to comply with Department of Energy orders, New Mexico environmental laws, and Environmental Protection Agency federal standards. The second aspect of the Laboratory process is to continuously improve performance. The third part of the process is an assessment program, which includes self-assessments, group assessments, management assessments, and audits from outside the Laboratory.

In the arena of environment, safety, and health, the Laboratory maintains air and water monitoring stations specifically to collect samples of data for quality checks. This monitoring is required by state and federal standards but is also a part of the Laboratory's commitment to help ensure the safety of the public and the environment.

\section{environmental oversight}

The Environmental Oversight and Monitoring Agreement in Principle (known as the AIP) between the Department of Energy and the State of New Mexico provides technical and financial support from the Department of Energy for state activities in environmental oversight, environmental surveys and sampling, site visits, and document review. 
During 1996, the New Mexico

Environment Department/AIP staff conducted oversight of several of the Laboratory's environmental programs. This independent monitoring program allows the Laboratory's data to be verified. Highlights of these activities are presented below.

The data collected from the thermoluminescent dosimeters were at or below natural background radiation levels at all locations.

The values for plutonium, americium, and uranium measured by the Department of Energy Oversight Bureau's stations, collocated with five of the Laboratory's monitoring stations, are all approximately two to three orders of magnitude below Department of Energy concentration guidelines.

An analysis of surface water and groundwater data collected from several years shows that contaminants were detected within each of the four saturated zones in the Los Alamos area. The largest and most diverse concentrations of contaminants in groundwater are found within canyon alluvium.

A preliminary comparison of historical radiological data for foodstuffs indicated that the data collected by the Department of Energy Oversight Bureau are consistent with the Laboratory's data. The Department of Energy Oversight Bureau staff actively participated in the planning and expedited cleanup of TA-9, Area $M$, an abandoned dump site. The bureau continued to work with the Environmental Protection Agency, Department of Energy, and the Laboratory to develop methods of evaluating potential release sites for risks to sensitive habitats or threatened or endangered species.

\section{environmental, safety, and health training}

The Laboratory maintains an extensive training program of environmental, safety, and health courses that meet compliance requirements under the Environmental Protection Agency, the Occupational Safety and Health Administration/Act (OSHA), and Department of Transportation regulations, as well as the Department of Energy. In 1996, training was available as classroom, self-study, computer-based, or on-line training in the following categories:

\section{- General Employee Training (for all} new employees, contractors, affiliates, long-term visitors, and students), which consists of introductory information on environment, safety, and health topics such as OSHA rights and responsibilities, industrial hygiene, industrial safety, fire protection, emergency management, and general employee radiological training; administrative policies; and security requirements.
- Environmental training, which includes courses on chemical and biological hazards, confined space entry, hearing conservation, respiratory protection, back care, first aid, and cardiopulmonary resuscitation.

- Safety training, which includes courses on cranes, forklifts, lasers, lockout/tagout, electrical safety, pressure safety, shop safety, welding safety, and OSHA standards.

\section{- Radiation safety training, which} includes courses for general workers, radiological workers, and radiological control technicians, in addition to courses on dosimetry, criticality, plutonium, tritium, and $\mathrm{x}$-rays.

\section{- Packaging and transportation} training, which includes courses on the identification, packaging, shipment, and transport of hazardous materials and wastes, radioactive materials and wastes, explosives, and gas cylinders.

All Laboratory-wide training is done in conjunction with subject matter experts who validate technical content.

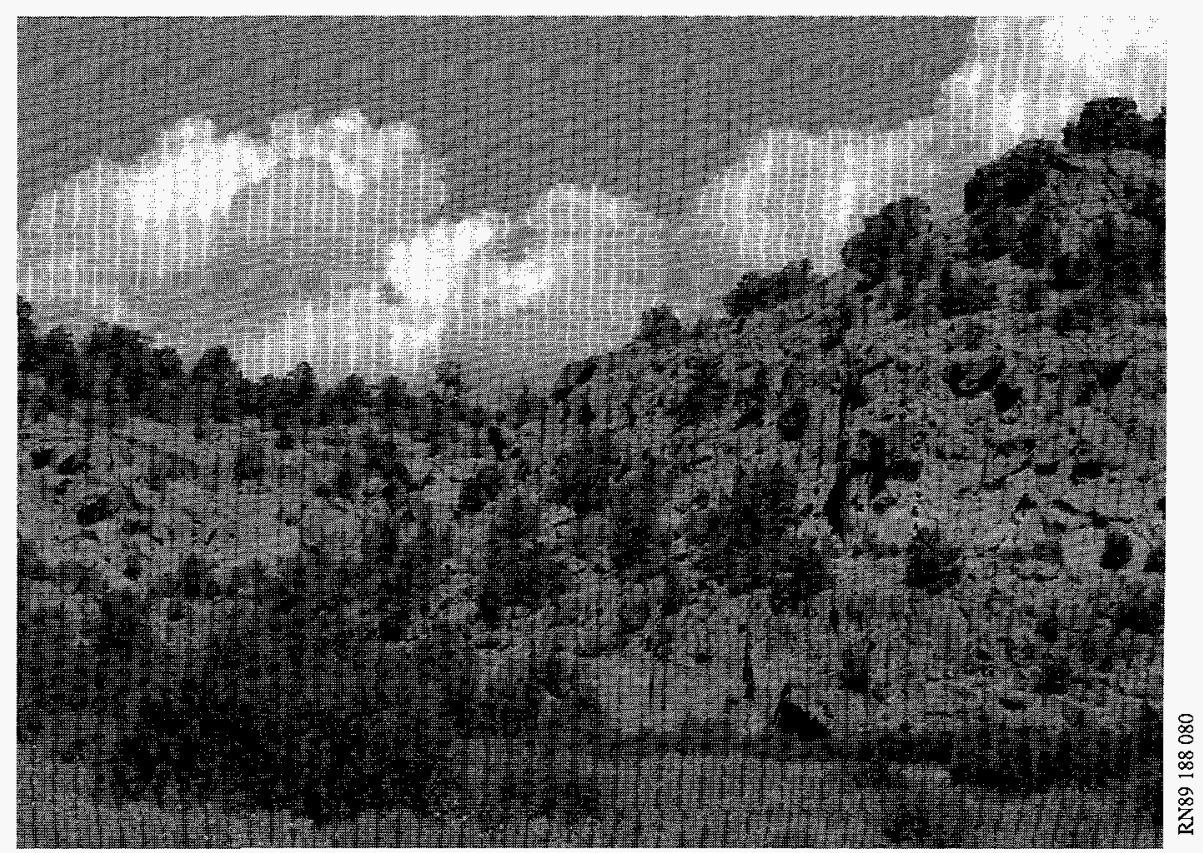




\section{Environmental Monitoring}

\section{external penetrating radiation}

Levels of external penetrating radiation (the radiation originating from a source outside the body, including $x$-rays and gamma rays and charged particle contributions from cosmic, terrestrial, and man-made sources) are measured with thermoluminescent dosimeters and dose rate monitors. Above-background doses were measured by environmental dosimeters and dose rate monitors near the Pajarito Canyon site (TA-18). The maximum total dose a frequent user of Pajarito Road might have received is a few millirem, below the Department of Energy's annual dose limit. Also, the dose rate monitor at East Gate measured an above-background dose of 1 to 2 mrem in 1996 .

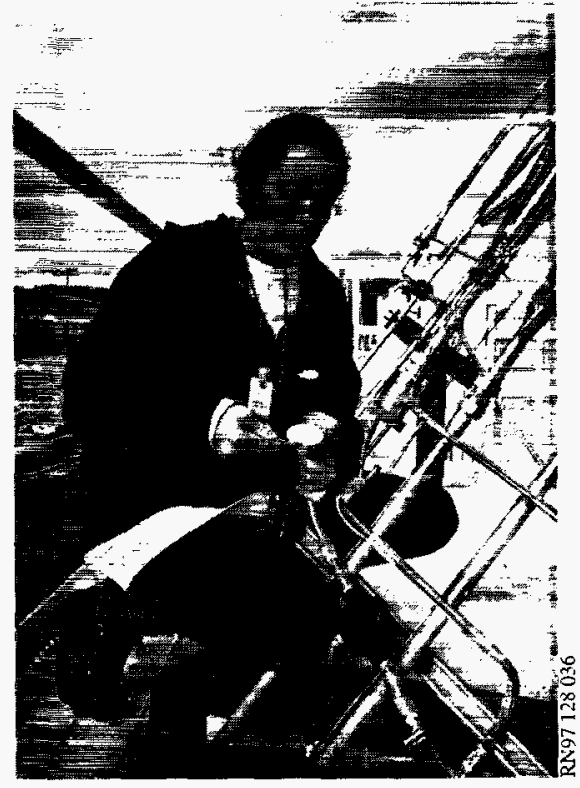

air

Air monitoring stations record concentrations of various radionuclides in the air. Concentrations of gross alpha and beta activity, tritium, plutonium, americium, and uranium are calculated. Gross alpha and beta activities are due almost entirely to the decay of natural radionuclides (primarily radon for alpha activity) and are dependent on variations in natural conditions, such as atmospheric pressure, temperature, and soil moisture. The differences typically seen in gross alpha and beta results for the various air monitoring stations are most likely attributable to these natural factors. The concentration levels of radionuclides allowed in the air are controlled by the Department of Energy's derived air concentration guides and Environmental Protection Agency regulations. In 1996, the Laboratory's off-site concentration levels of tritium, uranium, plutonium, and americium were well below any applicable standards; on-site concentration levels did not exceed the Department of Energy's derived air concentration guides. Environmental Protection Agency regulations are not applicable to on-site air monitoring stations but were also not exceeded at these stations.

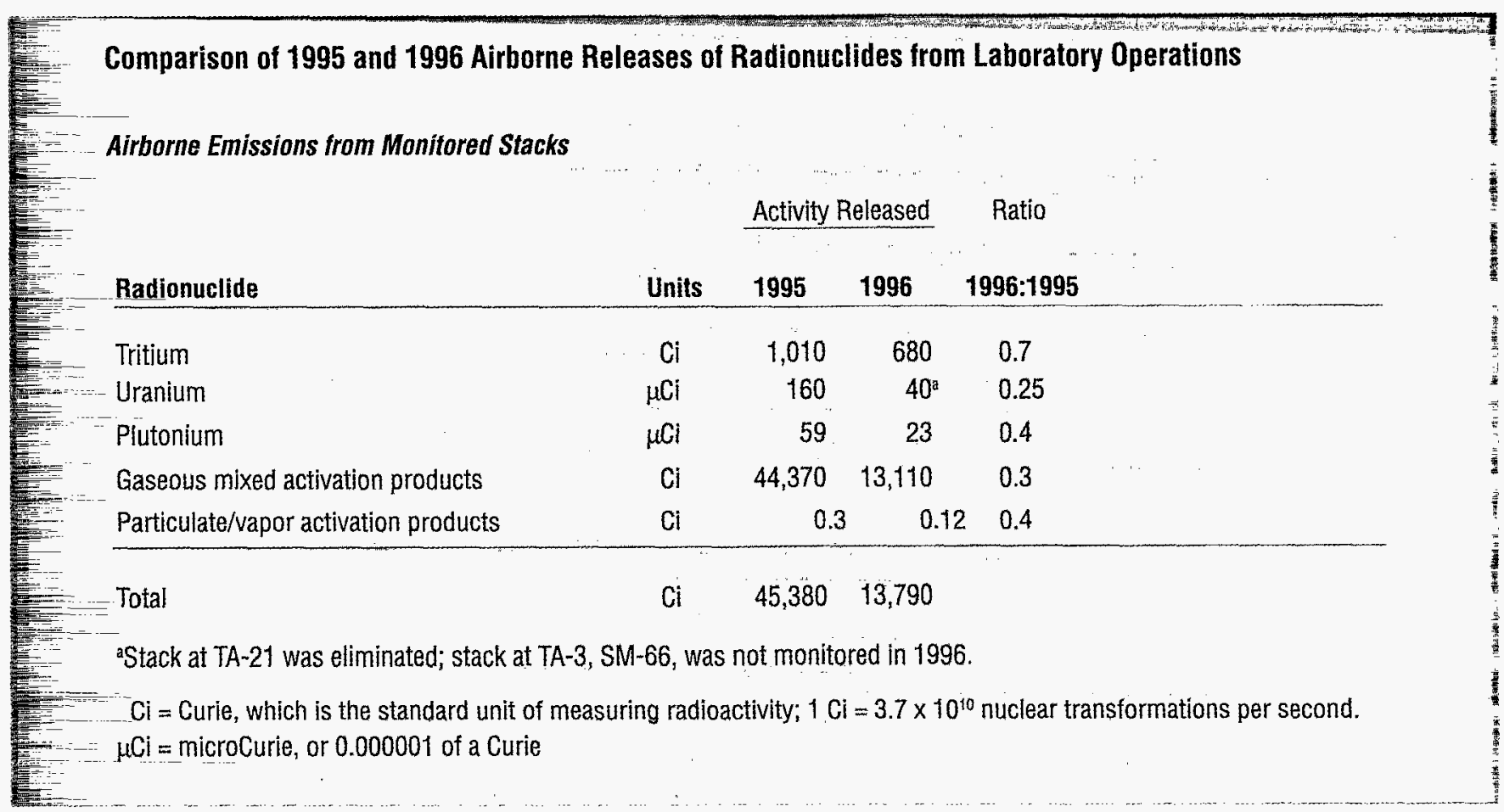




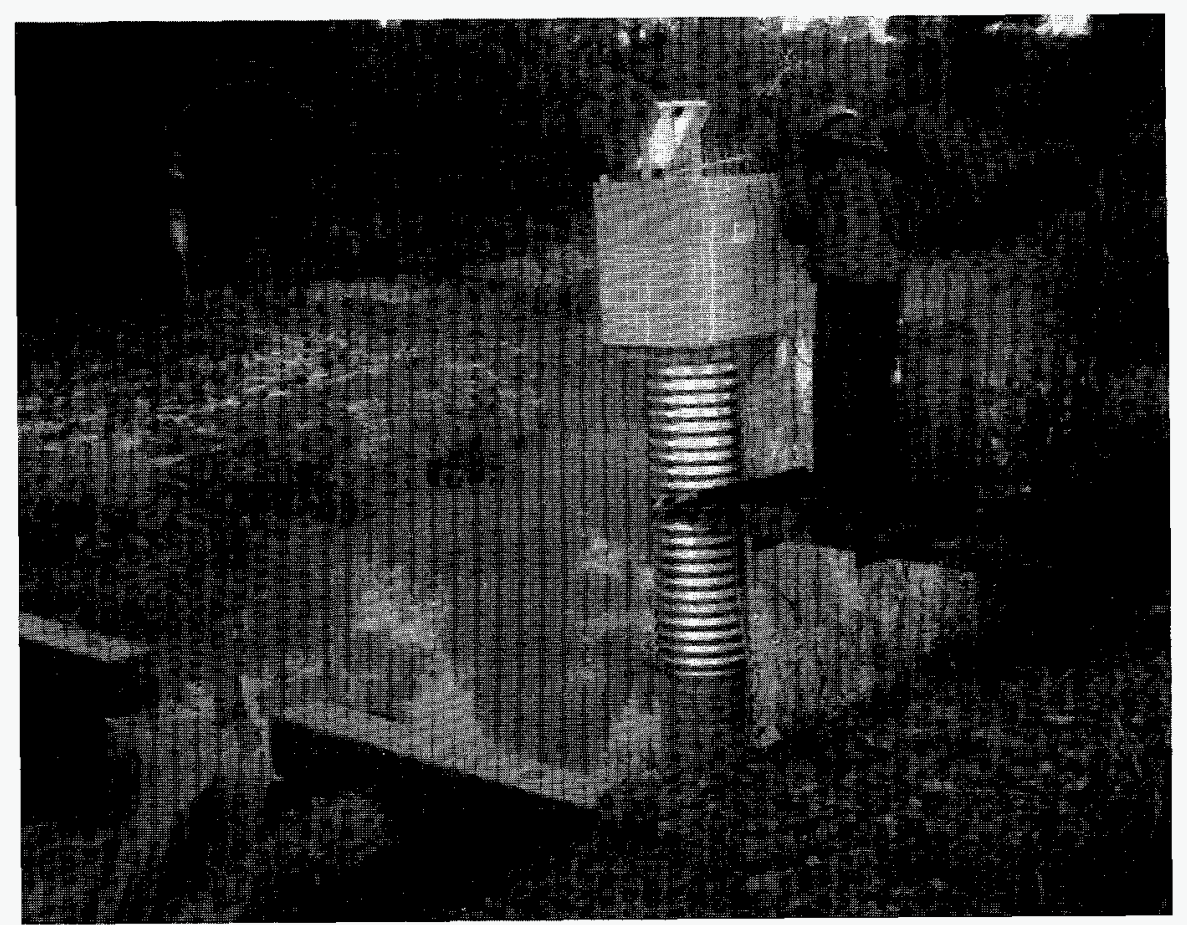

\section{water}

Within the Laboratory boundary, sources of surface water include spring snow-melt, summer storm runoff, and flow from outfalls that are permitted by the National Pollutant Discharge Elimination System of the Clean Water Act. Surface water is monitored on and adjacent to the Laboratory and at regional locations. Levels of plutonium, tritium, strontium, americium, uranium, cesium, alpha and beta particles, and gamma rays are measured at these stations. In 1996, all measurements were below the Department of Energy's derived concentration guides that limit potential exposure to the public for radioactive effluents in water. There has been a general downward trend in radioactive levels at most monitoring stations over the past three and a half decades. Surface water is monitored for its content of metals and inorganic chemicals to detect possible contami- nation resulting from Laboratory operations. Surface waters at the Laboratory are not a source of drinking or household water.

Groundwater is also monitored to determine its quality. The main aquifer beneath Los Alamos is the primary source of drinking water for the Laboratory and the residents of Los Alamos County. Operations at the Laboratory and discharges from county sewage treatment plants have resulted in detectable changes in water chemistry in some parts of the main aquifer. Several Laboratory test wells showed low levels of tritium resulting from Laboratory operations, but the levels were far below Environmental Protection Agency limits. Based on Environmental Protection Agency standards, these small changes have not degraded drinking water and are not a human health concern. There has been no significant depletion of the amount of water in the aquifer. 


\section{sediments}

Sediments are monitored on and near the Laboratory and at regional locations for the presence of tritium, uranium, plutonium, cesium, and strontium. In 1996, data from sediment sampling was consistent with results from previous years; none of the sediment samples showed any activity of radioactive substance that exceeded screening action levels (the level at which cleanup activity is required by the Environmental Restoration Project) except on Laboratory property in Mortandad Canyon where three stations exceeded the screening action levels for cesium-137. Sediments are also monitored for trace metals, such as antimony and mercury, and organic contaminants, such as polychlorinated biphenyls (PCBs). The 1996 results showed no concentrations above the limits of quantitation levels for trace metals and organic contaminants.

\section{soils}

Soils are monitored both on- and offsite for tritium, strontium, cesium, uranium, plutonium, americium, alpha and beta particles, and gamma rays. All levels were within acceptable values, and no action was required to reduce levels of any radioactive element in the soil. Soils are analyzed for trace and heavy metals, such as iron, lead, mercury, and aluminum. In 1996, all samples were within acceptable levels for the Los Alamos region.

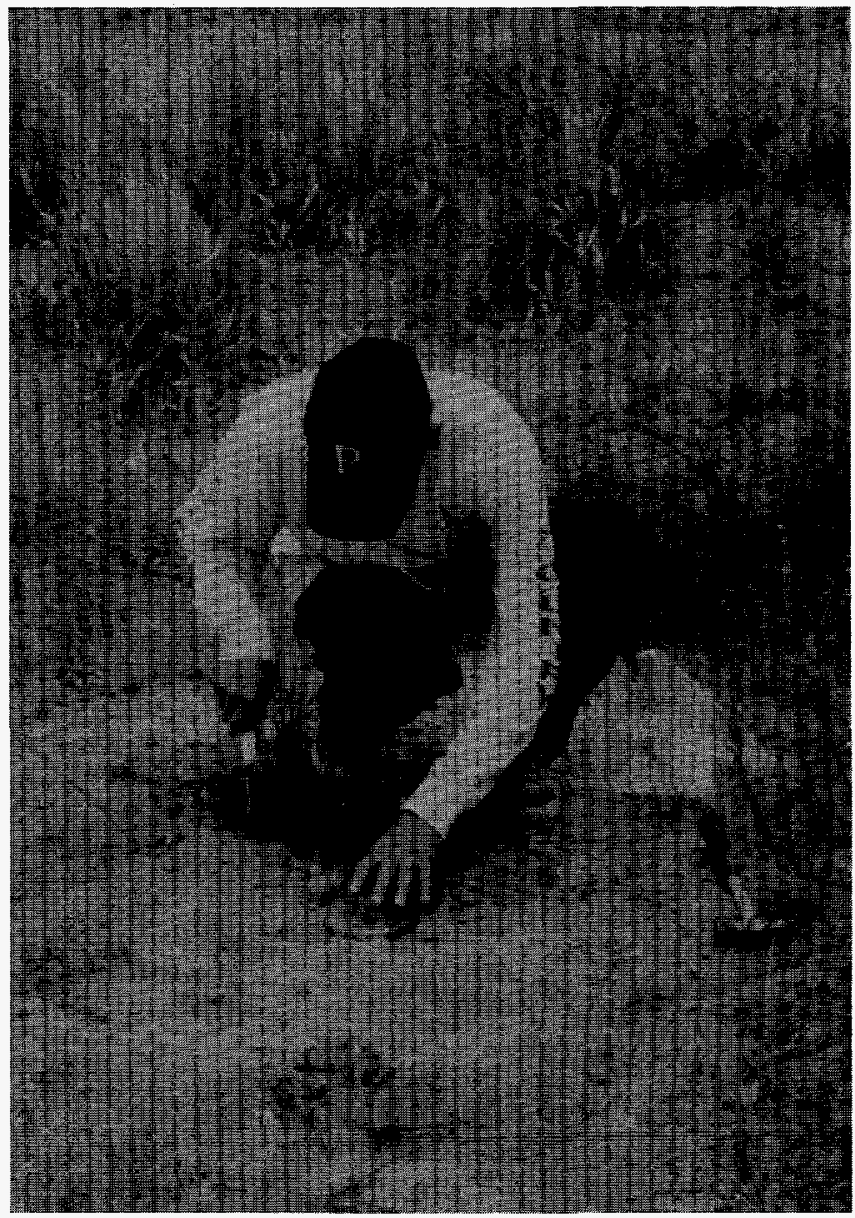

Trend analyses show that most radionuclides in soils, particularly tritium and uranium, from both onand off-site areas are decreasing over time. 


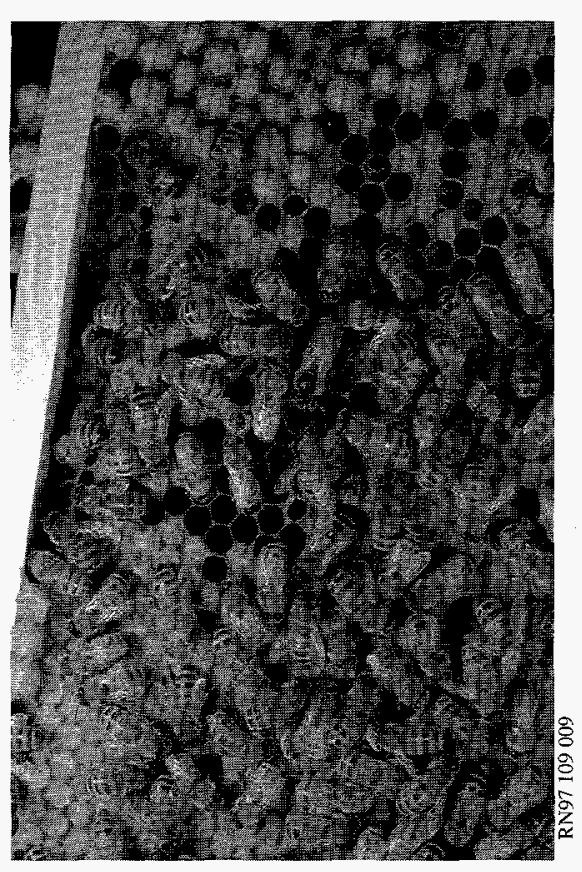

\section{foodstuffs and associated biota}

During 1996, samples of fruits, vegetables, herbal tea, honey, milk, eggs, fish, deer, elk, and domestic livestock were collected from the Laboratory and surrounding areas, including several Native American Pueblo communities, to determine the impact of Laboratory operations on the human food chain.

Most foodstuff samples from Laboratory and perimeter locations showed no radioactivity distinguishable from that attributable to natural sources and/ or worldwide fallout. Similarly, most heavy metal elements in produce from Laboratory and perimeter areas were within regional background concentrations.
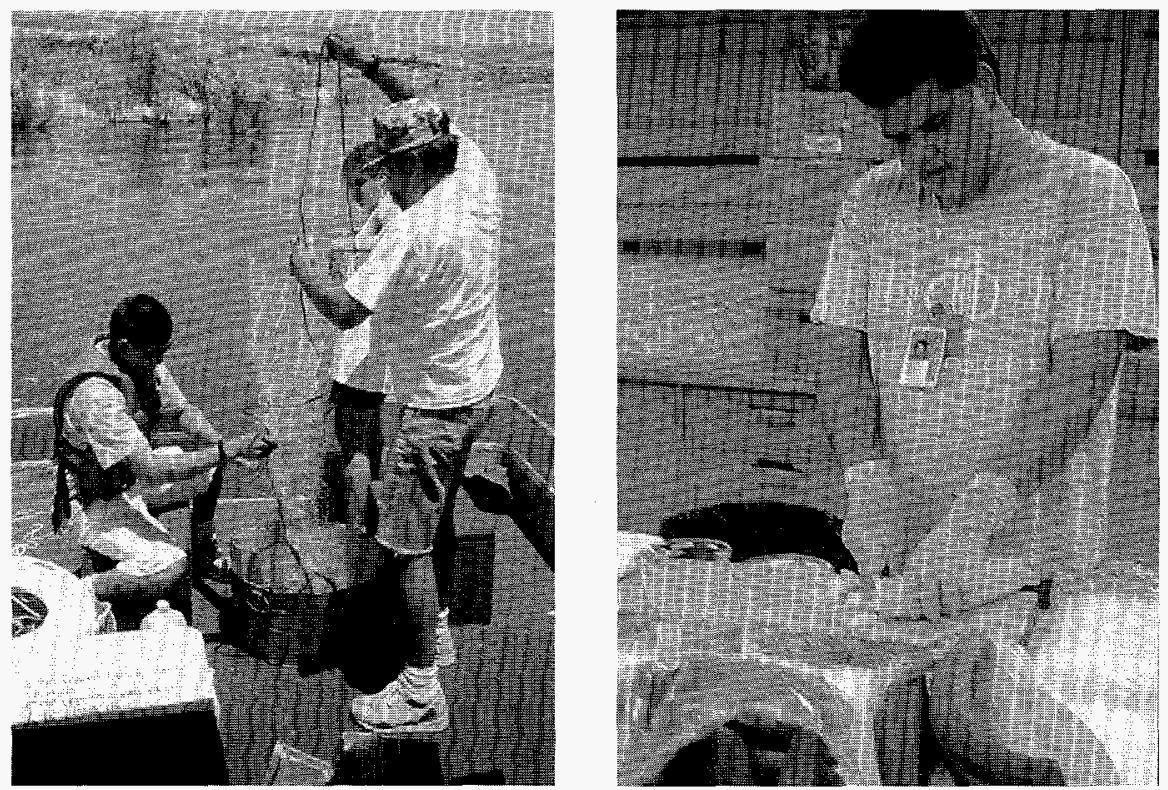


\section{Environmental Compliance}

The Laboratory operates under all applicable federal and state environmental, safety, and health laws, codes, orders, and standards. Environmental regulatory agencies include the Environmental Protection Agency and the New Mexico Environment Department. The Department of Energy issues orders that also regulate environmental activities at the Laboratory. Laboratory operations are subject to the following laws:

\section{Resource Conservation and Recovery Act (RCRA) and its Hazardous and Solid Waste Amendments (HSWA)}

RCRA requires the Laboratory to regulate hazardous and solid waste, from its generation to its disposal. RCRA requires the Laboratory to attempt to reduce the amount of hazardous waste produced, the toxicity of generated hazardous waste, and to treat hazardous waste before its disposal. Laboratory staff had frequent interactions with federal and state RCRA personnel during 1996. On October 4, 1995, the State of New Mexico issued the Federal Facility Compliance order (FFCO) to both the Department of Energy and the University of California requiring compliance with the Site Treatment Plan (STP) and thereby terminating the Federal Facility Compliance Agreement that had previously been in effect.

The New Mexico Environment Department conducted its annual hazardous waste compliance inspection from June 10 to 13, 1996. New Mexico Environment Department inspectors visited hazardous and mixed waste satellite accumulation areas, less-than90-day storage areas, and permitted and interim status storage and treatment facilities located throughout the Laboratory. On July 11, 1996, the New Mexico Environment Department sent the Department of Energy a Letter

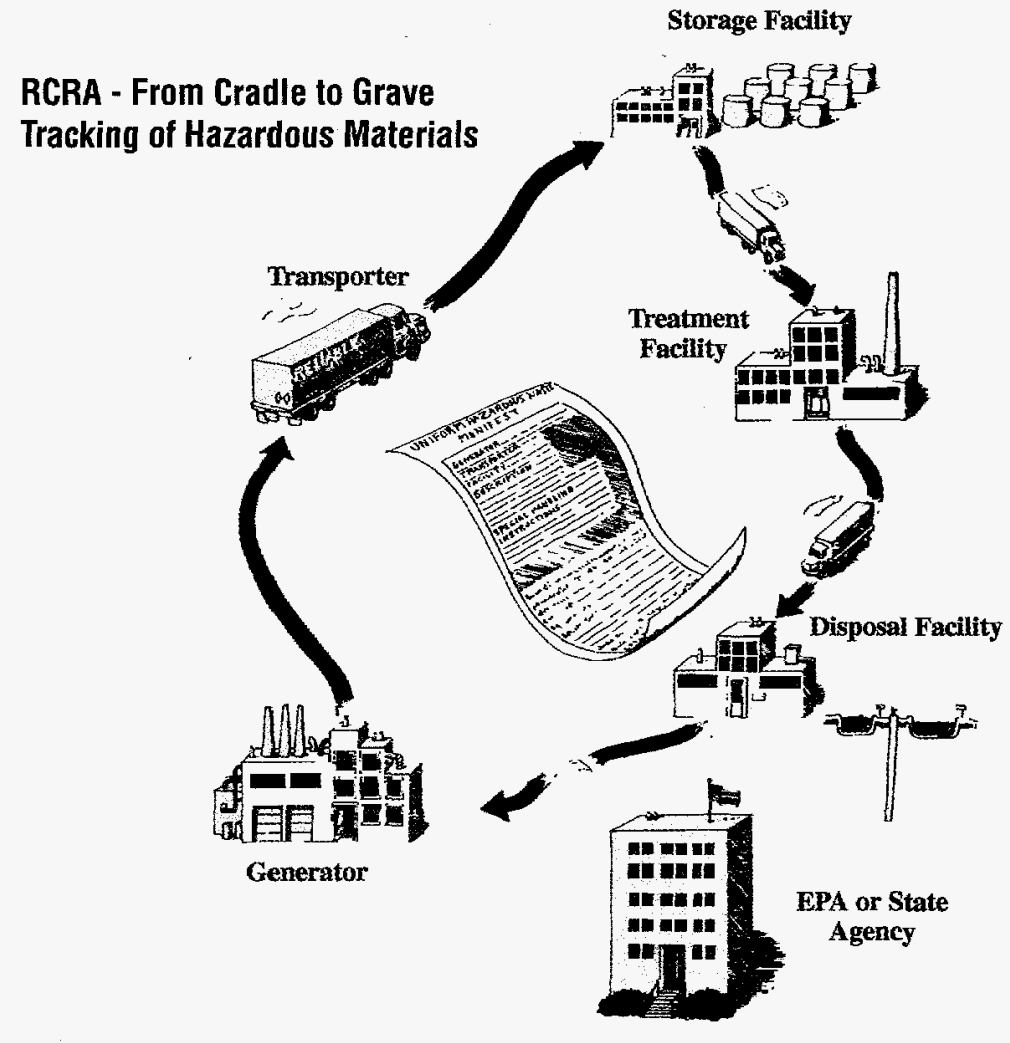

of Violation, an informal enforcement action, citing four violations that needed to be corrected. Those violations were satisfactorily addressed, and the inspection was closed out on August 15, 1996. No fines or penalties were assessed. In addition, the Department of Energy received a letter from the New Mexico Environment Department Director noting the Laboratory's improvement in hazardous waste regulatory compliance observed during the 1996 inspection.

One underground storage tank was removed from Laboratory property during 1996. The New Mexico Environment Department did not conduct an inspection of underground storage tanks in 1996.

In 1996, the activities conducted by the Environmental Restoration Project remained in compliance with Module VIII of the RCRA permit that incorpo- rates HSWA regulations. One Class 3 permit modification proposal was submitted in September 1996, requesting removal of 42 solid waste management units from the HSWA module list. The Environmental Restoration Project also recommended no further action for 84 areas of concern that are not on the HSWA module list. During 1996, an additional 292 sites were proposed for no further action in 44 field investigation reports submitted to the New Mexico Environment Department. The Environmental Restoration project also cleaned up 52 sites, including areas in the Los Alamos townsite. 


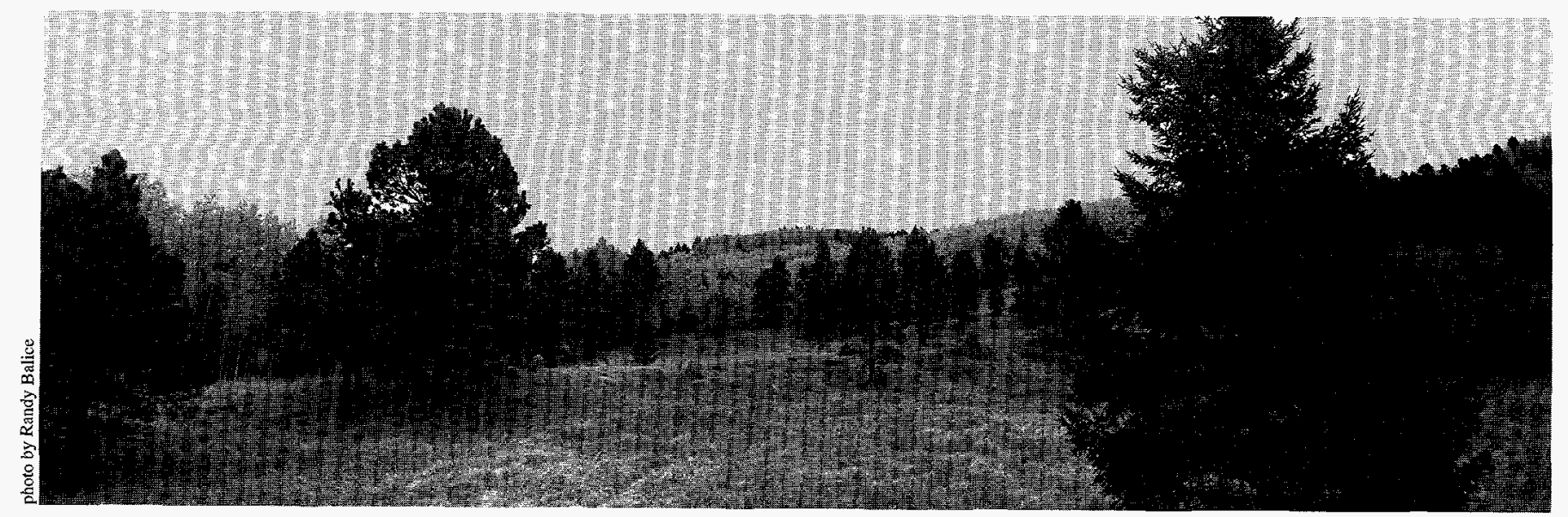

\section{Comprehensive Environmental Response, Compensation, and Liability Act (CERCLA)}

CERCLA outlines the appropriate responses to certain substance releases to the environment. Based on site assessments and inspections, the Environmental Protection Agency ranks potentially health threatening or environmentally unsound hazards at facilities. Special attention is given to these hazardous sites, which are maintained on a National Priority List. The Laboratory is not included on the National Priority List but is subject to the CERCLA guidelines for remediating Environmental Restoration Project sites that contain certain hazardous substances not covered by RCRA.

\section{Emergency Planning and Community Right-to-Know Act (EPCRA)}

EPCRA requires industrial production facilities to report their emissions to the environment. A Toxic Chemical Inventory Report must be submitted to the Environmental Protection Agency and the New Mexico Emergency Management Bureau every July for the preceding calendar year. The Toxic Chemical Inventory Report sent in 1996 includes the release of approximately 16,049 pounds of chlorine that were used to purify water, including cooling water from the power plant, discharges from sewage treatment plants, and drinking water. These water purification operations resulted in air emissions of 791 pounds of chloroform and 2 pounds of chlorine. An estimated 1,992 pounds of chlorine were released with the discharged water. The Laboratory files three additional reports in compliance with EPCRA: the Planning Notification report, the Extremely Hazardous Substances Release Notification, and the Material Data Safety Sheet/ Chemical Inventory report.

\section{Toxic Substances Control Act (TSCA)}

TSCA manages chemicals that may pose risks to humans or the environment. TSCA regulates the

Laboratory's use, storage, handling, and disposal of products and equipment containing PCBs that are commonly found in oil products and that may cause adverse health effects in humans.

In 1996, the Laboratory replaced two PCB-contaminated (greater than 50 and less than $500 \mathrm{ppm}$ ) transformers with non-PCB transformers. The Laboratory still operates 16 PCBcontaminated transformers that will be replaced as funding becomes available. The Laboratory, through Johnson Controls, Inc., completed its PCB survey in September 1996. In total, 2,023 structures were surveyed; 305 items were sampled for PCBs, and of those 305 items, 109 were identified by analysis as PCB items. The types of items surveyed include transformers, various pumps, oil-filled switches, light ballasts, generators, small transformers, and capacitors. If items are not in use or necessary for operations they are recommended for disposal.

In 1996, the Laboratory had 16 off-site shipments of PCB waste. The total weight of PCBs in those shipments was 87,682 pounds. PCB wastes are sent to Environmental Protection Agency-permitted disposal and treatment facilities.

The Environmental Protection Agency did not conduct an audit of the Laboratory's PCB management program during 1996.

On August 8, 1996, the Department of Energy, the Naval Nuclear Propulsion program, and the Environmental Protection Agency entered into a PCB Federal Facility Compliance Agreement, dealing specifically with radioactive $P C B$ and $P C B$ waste containing RCRA wastes. The Federal Facility Compliance Agreement is intended to be a compliance bridge from now until the Environmental Protection Agency's December 6, 1994, proposed rule updating the PCB regulations is final. The Laboratory has a total of 119 items that meet the criteria for inclusion in the PCB Federal Facility Compliance Agreement. 


\section{Federal Insecticide, Fungicide, and Rodenticide Act (FIFRA)}

FIFRA regulates the manufacturing and application of pesticides. The Laboratory is subject to FIFRA and the New Mexico Pest Control Act, which is administered by the New Mexico Department of Agriculture. The New Mexico Department of Agriculture did not audit the Laboratory's pesticide application program or its certified application equipment during 1996.

\section{Clean Air Act (CAA) and New Mexico Administrative Code (NMAC)}

The CAA and the NMAC are federal and state codes concerning air quality and emissions. Both radioactive and nonradioactive emissions to the air are screened carefully to protect the public, the ozone layer, and the environment. The effective dose equivalent from the Laboratory's 1996 radioactive air emissions was below the Environmental Protection Agency's limit of 10 millirem per year to any member of the public. The effective dose equivalent was calculated to be 1.93 millirem using methods that have been approved by the Environmental Protection Agency. In 1996, the Laboratory reviewed 60 construction or modification projects to determine if they could cause airborne radioactive emissions. After review, none of the projects required preconstruction approval.

The Laboratory, through the Department of Energy, signed a Federal Facility Compliance Agreement with the Environmental Protection Agency to comply with stack monitoring requirements. The Laboratory is meeting the terms of the agreement and has achieved full compliance in June 1996 with the regulations covering radioactive air emissions, as defined in the Federal Facility Compliance Agreement. The Laboratory was in compliance with all federal nonradiological ambient air quality standards.

\section{Clean Water Act (CWA)}

The primary goal of the CWA is to restore and maintain the chemical, physical, and biological integrity of the nation's waters. The three primary programs at the Laboratory established to comply with the CWA are the National Pollutant Discharge Elimination System (NPDES) program, the Spill Prevention Control and Countermeasures (SPCC) program, and the sewage sludge monitoring program.

The NPDES permits establish specific chemical, physical, and biological criteria that an effluent must meet before it is discharged. Although most of the Laboratory's effluent is discharged to normally dry arroyos, the Laboratory is required to meet effluent limitations under the NPDES permit program. The University of California and the Department of Energy are coowners on the permits covering Los Alamos. The permits are issued and enforced by the Environmental Protection Agency, Region 6, in Dallas, Texas. However, the New Mexico Environment Department performs some compliance evaluation inspections and monitoring for the Environmental Protection Agency through a Section 106 water quality grant. In 1996, Laboratory compliance for the sanitary and industrial waste discharges was $98.8 \%$ and $97.9 \%$, respectively.

Currently, the Laboratory has 13 NPDES General Permits for its storm water discharges. The conditions of these permits require the development and implementation of a Storm Water Pollution Prevention Plan and storm water runoff monitoring at selected facilities. During 1996, the Laboratory developed and implemented 75 Storm Water Pollution Prevention Plans for specific activities under the NPDES General Permit for storm water discharges.

The Laboratory also has an SPCC Plan, as required by the CWA. This plan requires the Laboratory to provide secondary containment for all aboveground storage tanks, and spill control on drum and container storage transfer, and loading/unloading areas.

During 1996, approximately 27 dry tons of sewage sludge were generated at the Laboratory's Sanitary Wastewater Systems Consolidation plant as part of routine wastewater treatment operations. Although analytical monitoring of this sludge in 1996 demonstrated $100 \%$ compliance with the minimum federal and Laboratory standards for land application, the detection of low concentrations (less than or equal to $4.38 \mathrm{ppm}$ ) of PCBs in the sludge prompted the Laboratory to suspend all land application activities in 1996. All sludge generated in 1996 is presently being stored on an asphalt pad at the Sanitary Wastewater Systems Consolidation plant while awaiting off-site disposal. 


\section{Safe Drinking Water Act (SDWA)}

Drinking water samples are routinely collected from the Laboratory, Los Alamos County, and Bandelier National Monument's water distribution systems and the Laboratory's water supply wellheads in order to determine the levels of microbiological organisms, organic and inorganic chemical constituents, and radioactivity in the drinking water. During 1996, all parameters regulated under the SDWA were in compliance with the maximum contaminant levels established by regulation. On May 22 , 1996, the New Mexico Environment Department inspected the drinking water system under the provisions of the New Mexico Drinking Water Regulations; no deficiencies were found, and the inspectors reported that the system was well maintained and supervised.

\section{National Environmental Policy Act (NEPA)}

NEPA requires federal agencies to consider the environmental impact of their actions before deciding to proceed with those actions. NEPA's objective is to maintain or restore compatibility between humanity and the environment, in the present and in the future. The Department of Energy, as the Laboratory's sponsoring agency, is responsible for preparation and approval of NEPA documents. Laboratory personnel reviewed 272 proposed Laboratory projects for NEPA during 1996.

NEPA also obligates the Laboratory to assess the impact of its projects on cultural resources; endangered, threatened, or sensitive species; and floodplains or wetlands. The protection of these resources is supported by the following legislation:
National Historic Protection Act, Native American Graves Protection and Repatriation Act, and American Indian Religious Freedom Act

Laboratory archaeologists evaluated 947 proposed actions for possible effects on cultural resources, which required 31 intensive field surveys. The Laboratory submitted 12 archeological survey reports to the New Mexico State Historic Preservation Officer and adjacent Native American Iribes for review and concurrence. No adverse effects to prehistoric cultural tresources were identified in 1996.

Endangered Species Act, New Mexico Wildlife Conservation Act, and New Mexico Endangered Plant Species Act

Laboratory biologists reviewed more than 500 proposed actions for potential impacts on threatened and endangered species; over 80 of the actions required additional study.

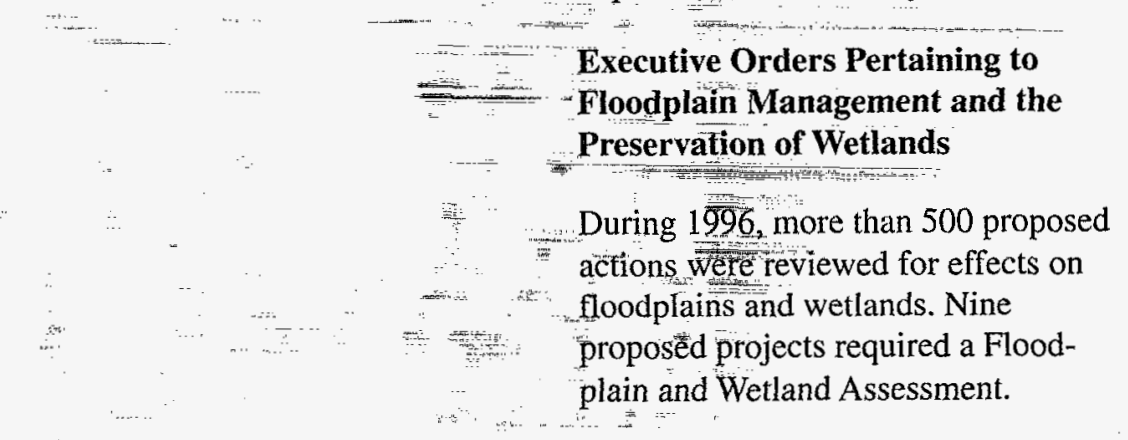


The Environmental Reports Team of the Ecology Group (ESH-20) would like to thank Karen Lyncoln, Louisa LujánPacheco, and Julie Johnston for updating this overview. We'd also like to thank the members of the following Los Alamos National Laboratory groups for their contributions to the booklet.

ESH-17, Air Quality,

ESH-18, Water Quality \& Hydrology

ESH-19, Hazardous \& Solid Waste

ESH-20, Ecology

EM, Environmental Management

This publication was produced by the Communication Arts \& Services Group (CIC-1).

Design: Karina Nilsson

Editing: Mable Amador

Illustration: Jim Mahan

Photography: CIC-9 where indicated by photo negative number; all other photos were provided by the client.

Illustration retrieval numbers:

page 3 esh $96-379 \mathrm{c}$

page 4 esh $96-365 c$

page 5 esh 96-377c, esh 96-378new

page 12 Environmental Protection Agency

Photography credit:

page 1 Randy Balice

page 6 ESH-19

page 9 ESH-18

page 10 ESH-20

page 11 ESH-20

page 13 Randy Balice

page 15 New Mexico Game and Fish

page 16 Randy Balice

Los Alamos National Laboratory, an affirmative action/equal opportunity employer, is operated by the University of California for the US Department of Energy under contract W-7405-ENG-36. All company names, logos, and products mentioned herein are trademarks of their respective companies. Reference to any specific company or product is not be construed as an endorsement of said company or product by the Regents of the University of California, the United States Government, the US Department of Energy, nor any of their employees. The Los Alamos National Laboratory strongly supports academic freedom and a researcher's right to publish; as an institution, however, the Laboratory does not endorse the viewpoint of a publication or guarantee its technical correctness. 